\title{
COMPARISON OF SELECTED DOMAINS OF QUALITY LIFESTYLE BETWEEN INDIANS AND INDIAN CANADIANS
}

\author{
J. S. Bains ${ }^{1}$ \\ ${ }^{1}$ Provincial Coordinator, Self-Management Programmes, University of Victoria, British Columbia, \\ Canada
}

Sagarika Bandyopadhyay ${ }^{2}$

${ }^{2}$ Professor, Department of Physical Education \& Sport Science, Visva-Bharati University, Santiniketan, India

Arup Gayen ${ }^{3}$

${ }^{3}$ Assistant Professor, Saheed A.C. Mahavidyalaya, South 24 Parganas, West Bengal, India

Article DOI: https://doi.org/10.36713/epra4983

\begin{abstract}
The quality of various domains in life leads to life satisfaction which is essential for a balanced existence. From the perspective of physical and mental health, family, education, employment, wealth, safety \& security to freedom, religious beliefs and the environment-all entities of a human life are involved to it. Attempt has been made to consider three major aspects of a quality life namely, mindful eating, physical activity and sleep hygiene to denote the status of behavioural habits of people living in India and Canada. 373 subjects, 234 from India and 139 from Canada, were selected conveniently for this study. It is observed that Canadian community is significantly superior in habits of mindful eating and physical activities in comparison to Indian subjects. However, no significant difference was found in sleep hygiene between the subjects living in India and Canada.
\end{abstract}

KEY WORDS: Mindful eating, Physical Activity, Sleep Hygiene

\section{INTRODUCTION}

The quality of life is a multidimensional concept that defines a standard level for emotional, physical, mental, social and spiritual wellbeing. It is associated with the goals, expectations, standards, and concerns of each individual living in different cultural systems (WHO, 1993) to lead a good life. Lifestyle is a key factor to enhance the quality of life. Thus, the quality of various components in life including physical, mental and spiritual health, family, education, employment, wealth, safety \& security, freedom, beliefs and the environment all encompass the quality of life. Physical activity is a behaviour that is bodily movement produced by contraction of skeletal muscles that require energy expenditure (ACSM, 2010) while sleep hygiene is vital for stress management. The quality of life, as a new health indicator, is not worried about how long people can live, but more concerned about how well they live. It is the exactness of negative and positive features of life.

Research shows that developing countries are at high risk of chronic diseases due to lifestyle habits. In a study, Jepson, R., et al (2012) indicated a twofold increased heart disease and fivefold increased risk of diabetes of South Asian people. With this background to focus on regular exercise, adequate sleep, and balanced demand of work and relaxation and over all positive health lifestyle habits for well-being of Indian-origin people, this study was undertaken. 


\section{EPRA International Journal of Research and Development (IJRD) \\ Volume: 5 | Issue: 8 | August 2020 \\ - Peer Reviewed Journal}

\section{Objectives}

The objectives of the study were to

i) assess the status of quality lifestyle of Indians and Indian Canadians

ii) compare quality of lifestyle between Indians living in India and Indian Canadians living in Canada

\section{METHODOLOGY}

Subjects: 373 people served as subjects for this study, out of which 234 (Male=128, Female=106) were selected from India and 139 (Male $=67$, Female=72) from Canada. The age group of the subjects ranged between 30 and 60 years.

Inclusion and Exclusion criteria:Two mixed groups of male and female subjects from two different countries were involved in the study. As the study deals with behavioural patterns and habits of the citizens, sex differentiation or age category were not considered separately.

Location:The data were collected using standard questionnaires from the states of Punjab and West Bengal in India and British Columbia in Canada.

Design:The sampling technique was convenient group design and two-group comparison method was adapted to the study.
Ethics: The process of approval of the study was initiated systematically to meet the requirements of regulated protocol and guidelines of the prestigious university of Visva-Bharati, India.

Criterion Measures: To achieve the objectives of the study,quality of life style was considered as the parameter, while three different variables such as Mindful Eating Habits, Physical Activities and Sleep Hygiene designated it. Mindful Eating Habit was characterised by fivedomains such as Awareness, Distraction, Dis-inhibition, Emotional Responses and External Cues. It was assessed by standardized 'Mindful Eating Questionnaire' with standard scoring tool, Physical Activity was assessed by International Physical Activity Questionnaire and the Sleep Hygiene was assessed by the Epworth Sleepiness Scale with standard scoring tools.

Statistical Procedure: To assess the status of two groups on lifestyle and comparebetween the groups on selected variables, the data were analysed by descriptive statistics and Independent ' $t$ ' test was computed using Microsoft excel and SPSS Software version 25 . The level of significance was set at 0.05 .

\section{FINDINGS \& INTERPRETATION}

The descriptive statistics of all the selected variables are presented in Table 1.

\begin{tabular}{|c|c|c|c|c|c|c|}
\hline \multicolumn{7}{|c|}{ Table 1: Descriptive Statistics of Selected Variables } \\
\hline Variables & Domains & Country Group & $\mathbf{N}$ & Mean & \pm SD & $\mathbf{\pm S E M}$ \\
\hline \multirow{10}{*}{$\begin{array}{l}\text { Mindful Eating Habits } \\
\text { (Score) }\end{array}$} & \multirow{2}{*}{ Awareness } & India & 234 & 2.24 & 0.46 & 0.03 \\
\hline & & Canada & 139 & 2.35 & 0.46 & 0.04 \\
\hline & \multirow{2}{*}{ Distraction } & India & 234 & 2.84 & 0.44 & 0.03 \\
\hline & & Canada & 139 & 2.91 & 0.46 & 0.04 \\
\hline & \multirow{2}{*}{ Dis-inhibition } & India & 234 & 2.69 & 0.39 & 0.03 \\
\hline & & Canada & 139 & 2.80 & 0.33 & 0.03 \\
\hline & \multirow{2}{*}{$\begin{array}{l}\text { Emotional } \\
\text { Response }\end{array}$} & India & 234 & 2.01 & 0.50 & 0.03 \\
\hline & & Canada & 139 & 2.15 & 0.53 & 0.04 \\
\hline & \multirow{2}{*}{ External cue } & India & 234 & 2.08 & 0.53 & 0.03 \\
\hline & & Canada & 139 & 2.16 & 0.51 & 0.04 \\
\hline \multirow{2}{*}{\multicolumn{2}{|c|}{ Mindful Eating Habits (composite score) }} & India & 234 & 2.37 & 0.23 & 0.02 \\
\hline & & Canada & 139 & 2.47 & 0.21 & 0.02 \\
\hline \multirow{2}{*}{\multicolumn{2}{|c|}{ Physical Activities (MET-hr/day) }} & India & 234 & 16.25 & 19.63 & 1.28 \\
\hline & & Canada & 139 & 26.80 & 69.21 & 5.87 \\
\hline \multirow{2}{*}{\multicolumn{2}{|c|}{ Sleep Hygiene (hrs/day) }} & India & 234 & 8.64 & 4.54 & 0.30 \\
\hline & & Canada & 139 & 7.82 & 4.31 & 0.37 \\
\hline \multicolumn{7}{|c|}{ Abbreviation: SD = Standard Deviation, SEM = Standard Error of Mean } \\
\hline
\end{tabular}




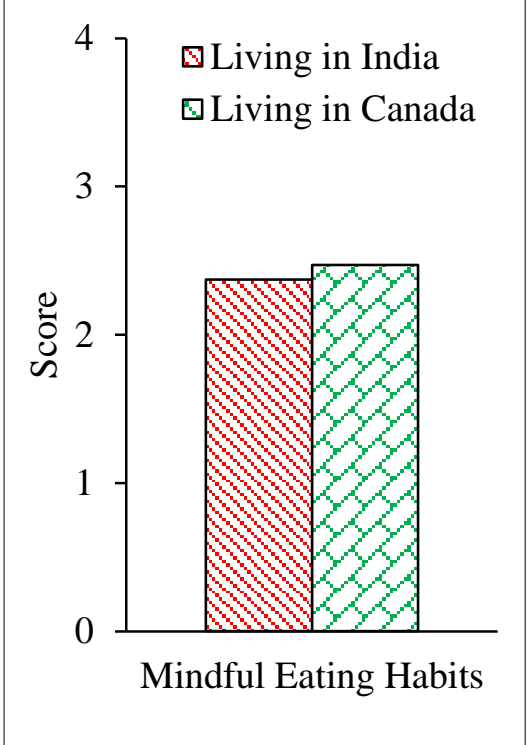

Figure 1: Graphical Representation of Mindful Eating Habit

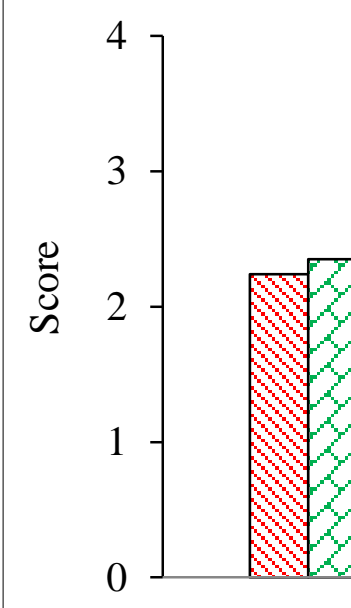

Awareness

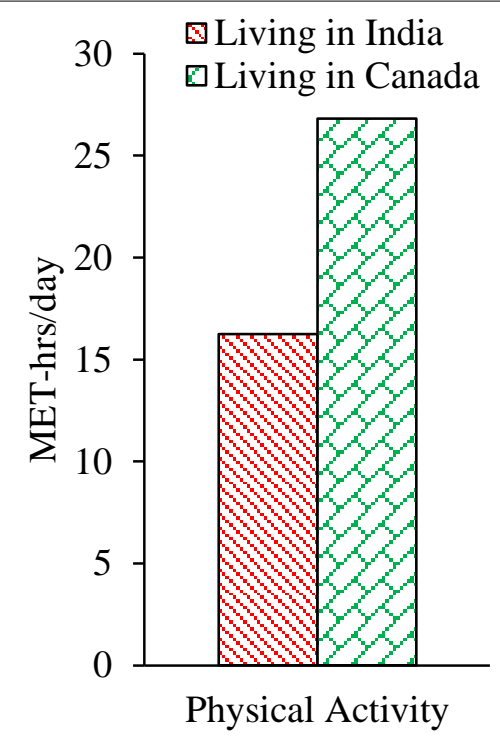

Figure 2: Graphical Representation of Physical Activity

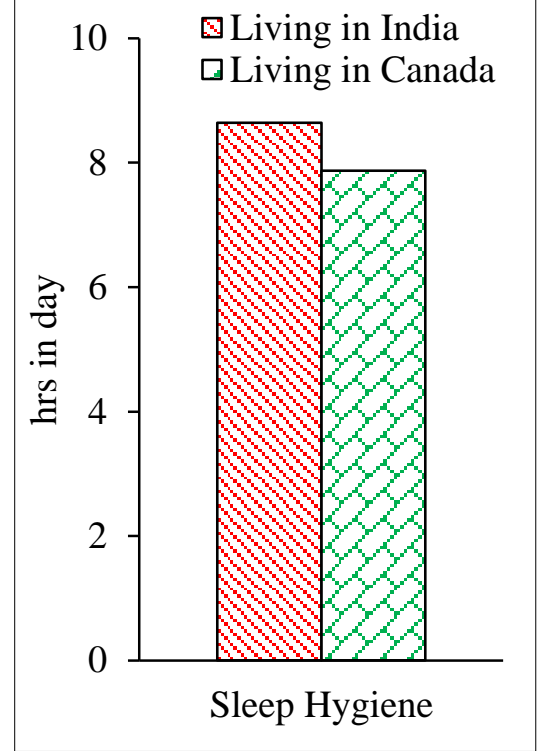

Figure 3: Graphical Representation of Sleep Hygiene

$\triangle$ Living India ๑Inving Canada

Figure 4: Graphical Representation of Five Domains of Mindful Eating Habit 


\section{EPRA International Journal of Research and Development (IJRD) \\ Volume: 5 | Issue: 8 | August 2020 \\ - Peer Reviewed Journal}

\begin{tabular}{|c|c|c|c|c|c|c|}
\hline Variables & Domains & Country & $\begin{array}{c}\text { Mean } \\
\text { Difference }\end{array}$ & $\begin{array}{l}\text { Std. Error } \\
\text { Difference }\end{array}$ & $\begin{array}{c}\mathrm{t}- \\
\text { ratio }\end{array}$ & $\begin{array}{l}\text { Sig. Level } \\
\text { (2-tailed) }\end{array}$ \\
\hline \multirow{10}{*}{$\begin{array}{l}\text { Mindful Eating } \\
\text { Habits(score) }\end{array}$} & \multirow{2}{*}{\begin{tabular}{|l} 
Awareness \\
(Higher score better) \\
\end{tabular}} & India & \multirow{2}{*}{0.11} & \multirow{2}{*}{0.05} & \multirow{2}{*}{$2.24^{*}$} & \multirow{2}{*}{0.026} \\
\hline & & Canada & & & & \\
\hline & \multirow{2}{*}{$\begin{array}{l}\text { Distraction } \\
\text { (Reversed score ) }\end{array}$} & India & \multirow{2}{*}{0.07} & \multirow{2}{*}{0.05} & \multirow{2}{*}{1.49} & \multirow{2}{*}{0.138} \\
\hline & & Canada & & & & \\
\hline & \multirow{2}{*}{$\begin{array}{l}\text { Dis-inhibition } \\
\text { (Reversed score ) }\end{array}$} & India & \multirow{2}{*}{0.11} & \multirow{2}{*}{0.04} & \multirow{2}{*}{$2.88^{*}$} & \multirow{2}{*}{0.004} \\
\hline & & Canada & & & & \\
\hline & \multirow{2}{*}{\begin{tabular}{|l|}
$\begin{array}{l}\text { Emotional Response } \\
\text { (Reversed score ) }\end{array}$ \\
\end{tabular}} & India & \multirow{2}{*}{0.14} & \multirow{2}{*}{0.05} & \multirow{2}{*}{$2.49^{*}$} & \multirow{2}{*}{0.013} \\
\hline & & Canada & & & & \\
\hline & \multirow{2}{*}{$\begin{array}{l}\text { ExternalCue(Reverse } \\
\text { d score ) }\end{array}$} & India & \multirow{2}{*}{0.08} & \multirow{2}{*}{0.06} & \multirow{2}{*}{1.39} & \multirow{2}{*}{0.165} \\
\hline & & Canada & & & & \\
\hline \multirow{2}{*}{\multicolumn{2}{|c|}{$\begin{array}{l}\text { Mindful Eating Habits } \\
\text { (composite score) }\end{array}$}} & India & \multirow{2}{*}{4.23} & \multirow{2}{*}{0.02} & \multirow{2}{*}{$4.23^{*}$} & \multirow{2}{*}{$\begin{array}{c}0.000 \\
\left(2.95 \times 10^{-5}\right)\end{array}$} \\
\hline & & Canada & & & & \\
\hline \multirow{2}{*}{\multicolumn{2}{|c|}{ Physical Activities (MET-hrs/day) }} & India & \multirow{2}{*}{2.19} & \multirow{2}{*}{4.82} & \multirow{2}{*}{$2.19^{*}$} & \multirow{2}{*}{0.029} \\
\hline & & Canada & & & & \\
\hline \multirow{2}{*}{\multicolumn{2}{|c|}{ Sleep Hygiene (hrs/day) }} & India & 082 & 048 & 171 & 0080 \\
\hline & & Canada & 0.82 & 0.48 & $1 . / 1$ & 0.088 \\
\hline & & Signific & 0.05 level & & & \\
\hline
\end{tabular}

Table 2 indicates that significant difference exists between the Indian and Canadian people in lifestyle so far as Mindful Eating Habits and Physical Activities are concerned. Subjects belonging to Canada were more aware, less inhibited and fairly emotional about mindful eating and they had significantly better Mindful Eating Habits in comparison to subjects living in India. Besides, the subjects living in Canada were found leading more physically active lifestyle in comparison to subjects living in India. However, no significant difference was found in sleep hygiene between subjects living in Canada and India.

The result might be due to the fact that the Government of developed countries like Canada provides ample health services to every citizen at par with their Health Policy, while over-populated India and its health policy failed to do so. In domains of Mindful eating habits like awareness, dis-inhibition, emotional response, Canadians were found superior to the Indians. Further, the reason for Canadian subjects to have better physical activity habits might be due to awareness and opportunity of physical activity followed by their mind-set.

Cho J., et al. (2019) suggested in their research that subjective health acts as a moderator in between psychological well-being and existing objective health of participants' experiences. Hall W., et al (2018) in their research revealed that sleep quality may be enhanced and behavioural eating habits may be improved through advice and diet controlling sugar.

\section{CONCLUSION}

On the basis of results of this study, it may be concluded that

i) In Mindful eating habits targeted population of Indian Canadians are significantly superior to their counterparts living in India. Their awareness, dis-inhibition and emotional responses were significantly better than Indians.

ii) In Physical Activity habits, Canadian subjects showed significant supremacy.

iii) However, in sleep hygiene score, subjects of both the countries are found balanced.

iv) Thus, it might be assessed that IndianCanadians living in Canada have better life style as compared to subjects living in India.

\section{REFERENCES}

1. ACSM's Resource Manual for Guidelines for Exercise Testing and Prescription, Wolters Kluwer, Lippincott Williams \& Wilkins, Sixth Edition

2. Banks S, Dinges DF. Behavioural and physiological consequences of sleep restriction. $J$ Clin Sleep Med. 2007; 3: 519-28

3. Bear RA, Smith GT, Allen KB, Assessment of mindfulness by self-report: The Kentucky Inventory of Mindfulness Skills. Assessment, 2004; 11: 191-206.

4. Bonnet MH, Alter J. Effects of irregular versus regular sleep schedules on performance, mood and body temperature. Biol Psychol. 1982; 14: 287-96. 


\section{EPRA International Journal of Research and Development (IJRD)

5. Boon RM, Hamlin MJ, Steel GD, Ross JJ: Validation of the New Zealand physical activity questionnaire (NZPAQ-LF) and the International Physical Activity Questionnaire (IPAQ-LF) with accelerometry. British Journal of Sports Medicine. 2010, 44: 741-746. 10.1136/bjsm.2008.052167.

6. Brand S, Holsboer-Trachsler E, Naranjo JR, Schmidst S. Influence of mindfulness oractice on cortisol and sleep in long-term and short-term mediators, Neuropsychobiology, 2012; 65: 10918 .

7. Brown KW, Ryan RM. The benefits of being present; Mindfulness and its role in psychological well-being. J PersSoc Psychol. 2003; 84: 822-848.

8. Buyses DJ, Cheng $Y$, Germain A, Moul DE, Franzen PL, Fletcher $M$, et al. Night-to-nightsleep variability in olde adults with and without chronic insomnia. Sleep Med. 2010; 11: 56-64.

9. Chen PH, Kuo HY, Chueh KH. Sleep hygiene education: efficacy on sleep quality in working women. J Nurs Res. 2010; 18: 283-9

10. Chinapaw MJM, Mokkink LB, van Poppel MNM, van Mechelen W, Terwee CB: Physical Activity questionnaires for youth: A systematic review of measurement properties. Sports Medicine. 2010, 40: 539-563. 10.2165/11530770- 00000000000000 .

11. Davidson RJ, Kabat-Zinn J, Schumacher J, Rosenkranz M, Muller D, Santorelli SF, Urbanowski F, Harrington A, Bonus K, Sheridon $J F$. Aleration in brain and immune function produced by mindfulness meditation. Psychosom Med, 2003; 65: 564-570.

12. Dhand R, Sohal H. Good sleep, bad sleep! The role of daytime nap in healthy adults. CurrOpinPulm Med. 2006; 12: 379-82.

13. Dinger MK, Behrens TK, Han JL: Validity and reliability of the International Physical Activity Questionnaire in college students. Americal Journal of Health Education. 2006, 37: 337-343.

14. Drake C, RoehrsT,Shambroom J, Roth T. Caffeine effects on sleep taken 0,3,or 6 hours before going to bed. J Clin Sleep Med. 2013; 11905-200.

15. Dzierzewski JM, Buman MP, Giacobbi PR, Jr, Roberts BL, Aiken-Morgan AT, Marsisk M, et al. Exercise and sleep in community -dwelling older adults: evidence of a reciprocal relationship. $J$

16. Ekelund U, Sepp H, Brage S, Becker W, Jakes R, Hennings $M$, Wareham NJ: Criterion- related validity of the last\&-day short term of the International Physical Activity Questionnaire in Swedish adults. Public Health Nutrition. 2006, 9: 258-266.

17. Freedson PS, Miller K: Objective monitoring of physical activity using motion sensors and heart rate. Research Quaterly for Exercise and Sport. 2000, 71: S21-S30.

18. Friedman L, Zeitzer JM, Mumenthaler MS. Role of healthy sleep practices: Alcohol/caffeine/exercise/scheduling. In: Sateia
MJ, Buysse DJ, editors. Insomnia: Diagnosis and Treatment. Informa; London: 2010: 260-7.

19. Goldman SE, Hall M, Boudreau R, Matthews KA, Cauley JA, Ancoli-Israel S, et al. Association between nighttime sleep and napping in older adults. Sleep. 2008; 31: 733-40.

20. Griefahn B, Brode P, Marks A, Basner $M$. Autonomic arousals related to traffic noise during sleep. Sleep. 2008; 31; 569-77.

21. Hauri P. Sleep hygiene. In: Hauri P, editor. Current Concepts: The Sleep Disorders. The Upjohn Company; Kalamazoo, MI: 1977; $21-35$

22. Hu FB, Li TY, Colditz GA, Willet WC, MansonJE: Television watching and other sedentary behaviours in relation to risk of obesity and type 2 diabetes mellitus in women, Journal of American Medical Association. 2003, 289: 17851791. 10.1001/jama.289.14.1785.

23. Kabar-Zinn J, Lipworth L, Burney R. The clinical use of mindfulness meditation for the selfregulation of chronic pain. J Behav Med, 1985; 8: 163-190.

24. Kabat-Zinn J. Mindfulness-based interventions in context: past, present and future. ClinPsycholSciPrac. 2003; 10: 144-56.

25. Kabat-ZinnJ,Massion A, Kristeller J, Peterson $L G$, Fletcher K, Pbert L, Lenderking W, Santoreli $S$. Effectiveness of mediation based stress reduction program. Am J Psychiatry. 1992; 149: 936-943.

26. Kaleth As, Ang DC, Chakr R, Tong Y: Validity and reliability of community health activities model program for seniors and short-form international physical activity questionnaire as physical activity assessment tools in patients with fibromyalgia. Diasability and Rehabilitation. 2010, 32: 353-359.

27. Kenneth. Shulman. Journal of Affective Disorders, Volume 46, issue 3. 1997; 175-182.

28. Knuth AG, Bacchieri G, Victoria CG, Hallal PC: Changes in physical activity among Brazilian adults over a 5-year period. Journal of Epidemiology and Community Health. 2010, 64: 591-595. 10.1136/jech. 2009.088526

29. Kristal AR, Littman AJ, Benitez, D, White E. Yoga practice is associated with attenuated weight gain in healthy, middle-aged men and women. AlternThe Health Med. 2005; 11: 28:33.

30. Macfarlane DJ, Lee CCY, Ho EyK, Chan KL, Chan DTS: Reliability and validity of the Chinese version of IPAQ (short last 7 days). Journal of Science and Medicine in Sport. 2007, 10: 45-51.

31. Melbourne Academic Mindfulness Interest Group, Mindfulness -based psychotherapies: A review of conceptional foundations, empirical evidence and practical considerations. Aust.N Z J Psychiatry. 2006; 40: 285-294.

32. Moore Hj, Ells LJ, Mclure SA, Crooks S, Cumbor $D$, Summerbell CD, Betterham AM: The development and evaluation of a novel computer program to assess previous-day dietary and physical activity behaviours in school children: The Synchronised Nutrition and Activity program 


\section{EPRA International Journal of Research and Development (IJRD)

(SNAP). British Journal of Nutrition. 2008, 99: 1266-1274.

33. Morita E, Miyazaki S, Okawa M. Pilot study on the effects of a 1-day sleep education program: influence on sleep of stopping alcohol intake at bedtime. Nagoya J Med Sci. 2012; 74: 359-65

34. Myllymaki T, Kyrolainen H, Savolainen K, Hokka $L$, JAkonen R, Juuti T, et al. Effects of vigorous late night exercise on sleep quality and cardiac autonomic activity. J Sleep Res. 2011; 20: 146-53

35. Pereira MA, FitzerGerald SJ, Gregg EW, Joswiak ML, Ryan WJ, Suminski RR, Utter AC, Zmuda JM: A collection of Physical Activity Questionnaires for health-related research. Medicine and Science in Sports and Exercise. 1997, 29: S1-205

36. Rangul V, Holmaen TL, Kurtze N, Cuypers $K$, Midthjell $K$ : Reliability and validity of two frequently used self-administered physical activity questionnaires in adolescents. BMC Medical Research Methodology. 2008, 8:471o.1186/1471-2288-8-47.

37. Roehrs T, Roth T. Caffeine: sleep and daytime sleepiness. Sleep Med Rev, 2008; 12: 53-62

38. Shapiro SL, Carlson LE, Freedman $B$. Mechanism of mindfulness. $J$ ChlinPsychol, 2006; 62: 373-386.

39. Shawn N. Katterman, Joyce A. Corsica, Brighid M. Kleinman, Megan M. Hood, Lisa M. Neckers, Eating Behaviours, volume 15, issue 2. 2014; 197-204.

40. Singh NA, Stavrinos TM, Scarbek Y, Galambos $G$, Liber C, Fiatarone Singh MA. A randomized controlled trial of high versus low intensity weight training versus general practioner care for clinical depression in older adults. J Gerontol A BiolSci Med Sci. 2005; 60: 768-76

41. Vandelanotte $C$, De Bourdeaudhuij IM, Philippaerts RM, Sjostrom M, Sallis JF: Realibility and validity of a computerized and Dutch version of the International Physical Activity Questionnaire (IPAQ). Journal of Physical Activity and Health. 2005, 2: 63-75.

42. Wansink B. Environmental factors that increase the food intake and consumption volume of unknowing consumers. Annu Rev Nutr. 2004; 24 : 455-479.

43. Wansink B. Painter JE, North J. Bottomless bowls: why visual cues of portion size may influence intake. Obes Res. 2005; 13: 93-100.

44. Warren TY, Barry V, Hooker SP, Sui X, Church $T S$, Blair SN: sedentary behaviours increase risk of cardiovascular disease mortality in men. Medicine and Science in Sports and Exercise. 2010, 42: 879-885. 10.1249/MSS.0b013e3181c3aa7e.

45. Yang PY, Ho KH, Chen HC, Chien MY. Exercise training on patients with chronic primary insomnia. J Clin Sleep Med. 2010; 6: 270-5.

46. Youngstedt SD, O'Conner PJ, Dishman RK. The effects of acute exercise on sleep: a quantitative sybthesis. Sleep. 1997; 20: 203-14
47. Youngstedt SD. Effects of exercise on Sleep. Clin Sport Med. 2005; 24: 355-65. 